\title{
Effect of streptozotocin-induced hyperglycaemia on androgen-binding protein in rat testis and epididymis
}

\author{
N. Kühn-Velten, R. Schermer and W.Staib \\ Institut für Physiologische Chemie II, University of Düsseldorf, FRG
}

\begin{abstract}
Summary. In adult male rats treated with streptozotocin 6 weeks before the experiments, androgen-binding protein concentration was increased in testicular tissue by $33 \%(p<$ $0.01)$ and reduced in epididymal tissue by $25 \%(p<0.005)$ in animals exhibiting severe hyperglycaemia as compared with animals remaining in normoglycaemia or moderate hyperglycaemia. Androgen-binding protein content was diminished in epididymal tissue by $40 \%(p<0.0005)$ but not changed in testicular tissue. If related to constant body weight, the sum of
\end{abstract}

testicular and epididymal androgen-binding protein was identical in both normo- and hyperglycaemic animals. This disturbance in androgen-binding protein distribution may be the consequence of altered testicular secretion or impaired transport of androgen-binding protein from testes to epididymides.

Key words: Androgen-binding protein, testis, epididymis, streptozotocin-diabetes, Sertoli cells.
Numerous studies have demonstrated impairment of fertility [1] and testicular endocrine function [1-4] to be late complications of streptozotocin-treated hypoinsulinaemic, hyperglycaemic male rats. In addition to reports on defective spermatogenesis [5-6] and indications of disturbances of pituitary gonadotropin secretion [1-3, 5-7], dysfunction of the Leydig cells resulting in diminished testosterone formation in these diabetic animals seems to be the most extensively investigated problem in this field [1-4].

In contrast, less attention has been drawn to Sertoli cell function in diabetic animals. Although a specific androgen-binding protein (ABP) was shown several years ago to be a marker of Sertoli cell function [8-13], $\mathrm{ABP}$ measurements in diabetic rats have been reported in only one study [2]. A paradoxical increase of ABP content (expressed as $\mu$-equivalent of epididymal cytosol standard) of the testes (the site of production) but no change of ABP content of the epididymis (a possible site of action) has been found in rats 4 weeks after streptozotocin injection [2].

The aims of the present study on streptozotocintreated male rats were to re-evaluate those results, to distinguish between ABP concentrations and ABP content of testes and epididymides by consideration of changes in organ weights and to make correlations between testicular or epididymal ABP and blood glucose levels in order to prove possible diabetes-induced changes in testicular ABP secretion.

\section{Materials and methods}

Eighteen male Han: Wistar rats, weighing $214 \pm 5 \mathrm{~g}$ (mean \pm SEM) at the beginning of the study, received $65 \mathrm{mg}$ streptozotocin (2-desoxy2-(3-methyl-3-nitrosurea)-1 $\alpha$-glucopyranose; Calbiochem, Gießen, FRG) $/ \mathrm{kg}$ body weight, i.p. (experimental group). One rat died during week 3 . Five animals ( $205 \pm 5 \mathrm{~g}$ initial body weight) were injected with citrate buffer only and served as a control group. All animals were allowed food (Altromin 1314; Altromin, Lage, FRG) and tap water ad libitum.

Post-prandial blood glucose levels were examined routinely (seven times during the 6-week period of the experiment) using the Eyetone reflectometer system (Dextrostix; Ames-Miles, Frankfurt/Main, FRG). Urinary excretion of glucose and ketone bodies was measured with the Keto-Diabur 5000 test (Boehringer, Mannheim, FRG).

The experimental group was divided into two subgroups. Group 1 consisted of nine animals exhibiting normo- or moderate hyperglycaemia (mean blood glucose levels $<15 \mathrm{mmol} / 1$; glycosuria $>3 \%$ in one, ketonuria in none of the animals). Group 2 consisted of eight animals exhibiting severe hyperglycaemia (mean blood glucose $>15 \mathrm{mmol} / 1$; glycosuria $>3 \%$ in all, ketonuria + or ++ in five of the animals).

Animals were sacrificed 6 weeks after streptozotocin administration. Both epididymides and the left testis were removed for ABP measurement, decapsulated, trimmed of fat and weighed. Epididymides were minced with scissors and homogenized in six volumes, and testes in three volumes of Tris- $\mathrm{HCl}(50 \mathrm{mmol} / \mathrm{l}), \mathrm{Na}_{2}$ EDTA (1 mmol/1), $\mathrm{KCl}(80 \mathrm{mmol} / \mathrm{l}), 3$-mercapto-1,2-propandiol $(12 \mathrm{mmol} /$ 1), $10 \%$ glycerol $(\mathrm{v} / \mathrm{v}) \mathrm{pH} 7.4$ (TEMG-buffer). All reagents were of analytical grade and purchased either from Merck, Darmstadt, FRG or from Sigma Chemie, München, FRG. A glass-glass Duall homogenizer was used (Kontes Scientific Glassware, Vineland, NJ, USA). Epididymis and testis homogenates were centrifuged at $150000 \mathrm{~g}$ for $45 \mathrm{~min}$, the lipid layer discharged and the cytosol mixed with the $4000 \mathrm{~g}$ pellet of an equal volume of charcoal $(5 \mathrm{~g} / \mathrm{l})$, dextran T-70 


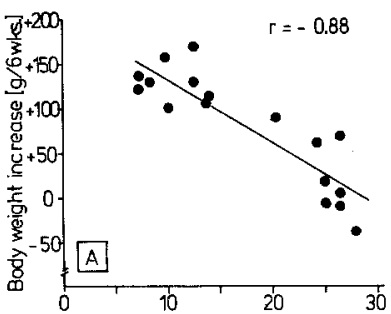

Mean blood glucose [mmol/l]

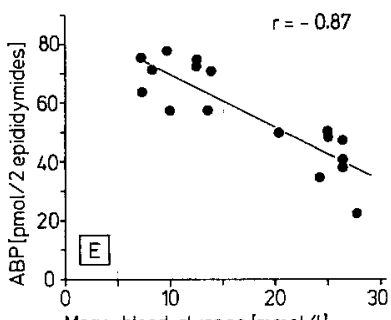

Mean blood glucose $[\mathrm{mmol} / /]$

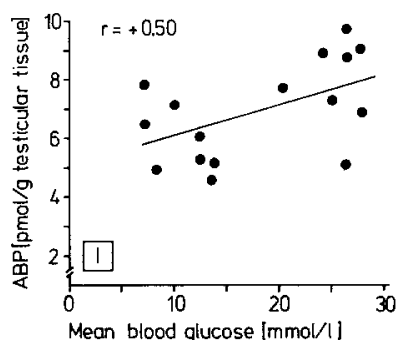

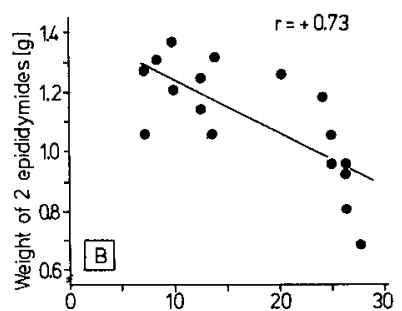

Mean blood glucose [mmol/l]

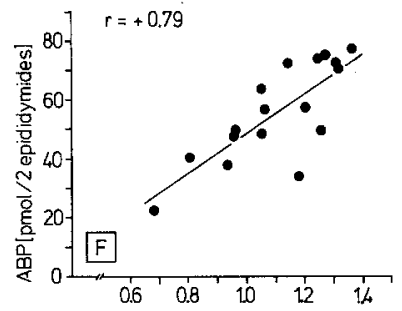

Weight of 2 epididymides $[\mathrm{g}]$

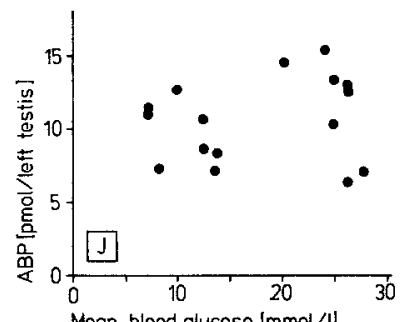

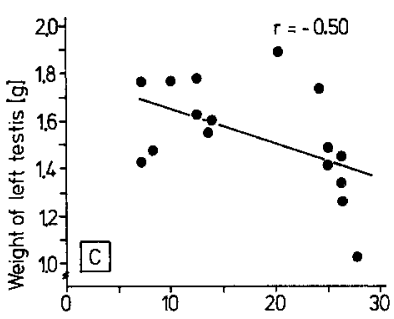

Mean blood glucose $[\mathrm{mmol} / \mathrm{l}]$
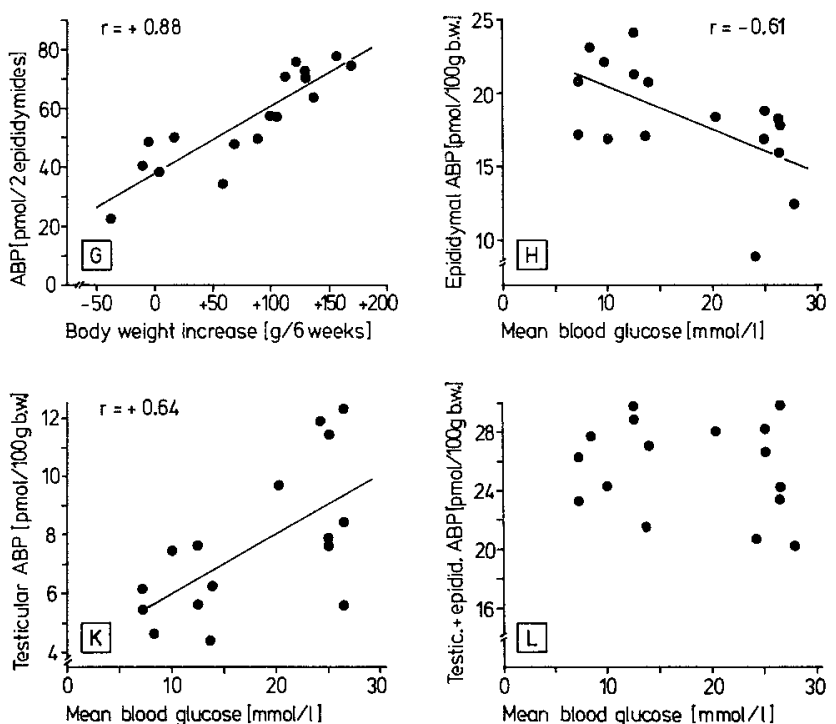

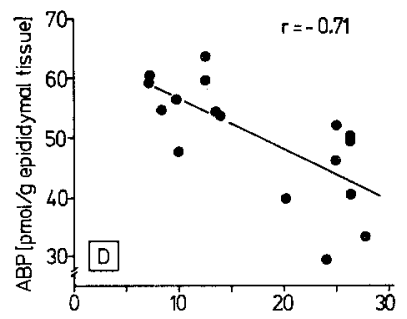

Mean blood glucose [mmol/l]

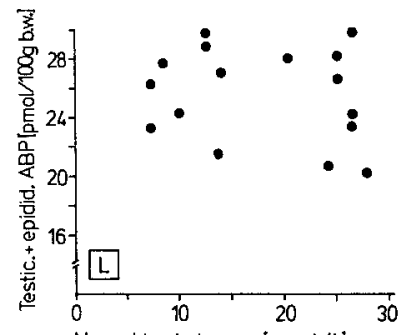

Mean blood glucose [mmol/l]

Fig. 1 A-L. Dependence of body and organ weights (A-C), epididymal (D-H), testicular (I-K) and total ABP (L) on mean blood glucose levels (A-E, H-L), organ weight (F) or body weight increase $(\mathbf{G})$ in streptozotocin-treated rats 6 weeks after administration of the drug. Regression lines are drawn only if there was a significant correlation $(p<0.05)$

Table 1. Control parameters and androgen-binding protein in streptozotocin-treated and control rats

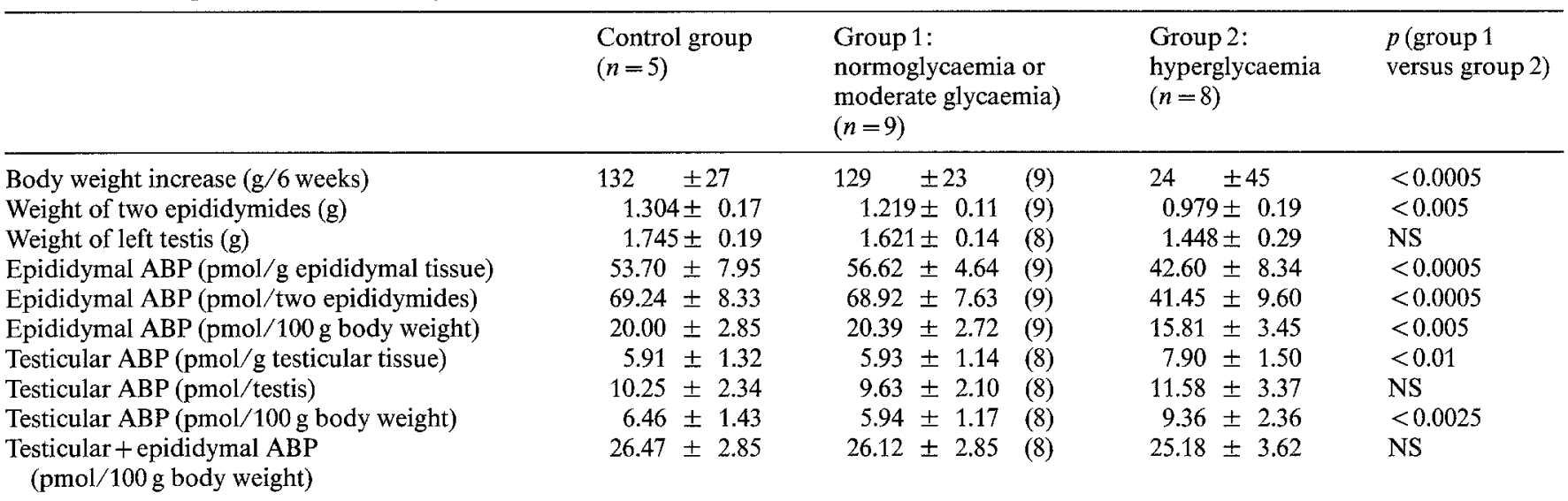

Results expressed as mean \pm SEM with number of animals given in parentheses. NS $=$ not significant

$(0.5 \mathrm{~g} / 1)$ (Pharmacia Fine Chemicals, Freiburg, FRG) in TEMG-buffer. After continuous shaking for $2 \mathrm{~h}$ at $2^{\circ} \mathrm{C}$ (in order to remove endogenous cytosolic steroids), the suspensions were centrifuged at $4000 \mathrm{~g}$ for $10 \mathrm{~min}$. Aliquots $(400 \mu \mathrm{l})$ of the supernatants were incubated for $15 \mathrm{~h}$ at $2{ }^{\circ} \mathrm{C}$ with a mixture of $50 \mu$ glycerol containing 2 pmol $\left[1,2-{ }^{3} \mathrm{H}(\mathrm{N})\right]$-dihydrotestosterone (DHT; $5 \alpha$-androstan- $17 \beta$-ol-3-one; spec. act. $1.48 \mathrm{TBq} / \mathrm{mmol}$; New England Nuclear, Dreieich, FRG) to achieve final ${ }^{3} \mathrm{H}-\mathrm{DHT}$ concentrations of $4 \mathrm{nmol} / 1$.

ABP concentrations in these cytosols equilibrated with ${ }^{3} \mathrm{H}-\mathrm{DHT}$ were determined by steady-state polyacrylamide gel electrophoresis as described elsewhere $[9,14,15]$ with the following modifications:
$100 \mu \mathrm{l}$ of the ${ }^{3} \mathrm{H}$-DHT-labelled cytosol were layered on $7 \%$ acrylamide rod gels $(85 \mathrm{~mm} \times 5 \mathrm{~mm})$ containing glycerol $(2.5 \%)$ and ${ }^{3} \mathrm{H}$-DHT $4 \mathrm{nmol} / 1$. Electrophoresis was run for $4 \mathrm{~h}$ at $3 \mathrm{~mA} / \mathrm{gel}$. Following electrophoresis, gels were frozen in n-hexane on dry ice and then thawing gels were sliced into $1-\mathrm{mm}$-thick pieces. Slices were counted for radioactivity $48 \mathrm{~h}$ after addition of scintillation fluid (Quickszint 212; Zinsser, Frankfurt/Main, FRG) with an efficiency of $32 \%$ in a TriCarb model 2650 spectrometer (Packard, Frankfurt/Main, FRG). The ABP content was normally calculated from five fractions $\left(R_{f}=0.46\right)$ with elevated radioactivity (in comparison to the basal activity) and could be clearly distinguished [8] from a small peak representing se- 
rum albumin $\left(R_{f}=0.67\right)$. A third peak of radioactivity reported to represent androgen receptor [15] could not be detected. The sensitivity of the method under these conditions is $15 \mathrm{fmol} \mathrm{ABP} / \mathrm{gel}$ assuming one binding site/molecule.

Correlation of ABP with control parameters, e.g. mean blood glucose levels, was proved by linear regression analysis with the least squares method. Differences between groups were analyzed using Student's t-test.

\section{Results}

Body weight increase (Fig. 1 A), weight of epididymides (Fig. 1B) as well as testicular weight (Fig. 1C) showed negative correlations with mean blood glucose levels. Body weight increase and epididymal weight were reduced if group 2 was compared to group 1, but no difference existed between testicular weights in both groups (Table 1). The control group and group $1 \mathrm{did}$ not differ significantly with regard to any of the variables tested.

A distinct reduction of both $\mathrm{ABP}$ concentration (Fig. 1D, Table 1) and ABP content (Fig.1 E, Table 1) in epididymides occurred with increasing mean blood glucose levels irrespective of the method of testing significant differences (regression analysis or t-test). Due to the positive correlation of epididymal ABP content with the epididymidal weight (Fig. 1F) the drop of ABP content in epididymides from hyperglycaemic rats resulted from both reduced ABP concentration and reduced epididymal weight. A positive correlation of epididymal ABP content with body weight increase (Fig. $1 \mathrm{G}$ ) was obtained. Nevertheless, epididymal ABP content was still significantly reduced in hyperglycaemic animals if related to constant body weight (Fig. $1 \mathrm{H}$, Table 1 ).

In contrast to the epididymis, ABP concentrations in the testes were higher in severely hyperglycaemic than in normo- or moderate hyperglycaemic rats (Fig.1I, Table 1). Due to slightly reduced testicular weight in hyperglycaemic animals (Fig. 1C), the total ABP content of testicular tissue was not changed (Fig. 1 J, Table 1). However, testicular ABP content was increased in hyperglycaemic animals if related to constant body weight (Fig. $1 \mathrm{~K}$, Table 1 ). The sum of ABP contents of both testes and epididymides was not influenced by hyperglycaemia (Fig. $1 \mathrm{~L}$, Table 1). Therefore streptozotocin-induced hyperglycaemia resulted in a shift of $A B P$ distribution from the epididymides back to the testes but not in a real increase or decrease of total ABP.

\section{Discussion}

In most of the previous studies on reproductive and especially endocrine testicular function of streptozotocindiabetic male rats, animals not exhibiting glycosuria or other criteria of diabetes mellitus were excluded from the experiments and a control group was established which received buffer injections only $[1,2,4,6]$. The protocol chosen in the present study, however, excluded possible side-effects of the drug. With all streptozotocin-injected animals included in the study irrespective of the outcome of the treatment, it was possible to look into the dependence of reproductive function parameters on the degree of hyperglycaemia. On the other hand, the direct comparison of the untreated control group with group 1 one of the experimental group allows the conclusion that streptozotocin itself does not affect testicular or epididymal ABP (Table 1).

With the protocol chosen for the present study, the effectiveness of diabetogenesis was comparable to that achieved previously by other authors [1]. A marked reduction of epididymal weight and only a slight reduction of testicular weight occurred in streptozotocin-diabetic animals (Fig. 1). Under slightly different conditions, a $20 \%$ loss $[1,5,6]$ or no change $[2,4,7]$ of testicular weight has been reported, whereas epididymal weight has been shown to be reduced by $50 \%$ [1] or by $15 \%$ [2]. Whether this loss in epididymal weight can be attributed to decreased serum testosterone levels in the diabetic rats remains questionable $[1,4,7]$. Alternatively, a slower increase of epididymal weight during development of diabetic rats may be the simple consequence of the slower increase in body weight.

The reason why epididymal ABP concentration, as well as epididymal ABP content, were decreased in diabetic in comparison with normoglycaemic adult rats is at first unclear. Two hypotheses may be discussed: (1) is it possible that decreased epididymal ABP levels are due to decreased serum FSH levels? Serum FSH concentrations have been reported to be decreased in streptozotocin-diabetic animals [2], but this finding has not been confirmed by other authors [3, 7]. FSH has been proposed to enhance both testicular and epididymal ABP concentrations $[8,9,11]$ as well as the ABP production by cultured Sertoli cells from immature rats [12]. Therefore possibly reduced circulating FSH concentrations in streptozotocin-diabetic male rats may result in a diminution of epididymal ABP but cannot explain increased testicular ABP concentrations. (2) Is it possible that decreased $\mathrm{ABP}$ levels are due to decreased serum testosterone levels? A reduction in circulating testosterone concentration has been observed in diabetic animals $[1-4,7]$. Testosterone administration to normal rats results in elevated testicular and epididymal ABP levels either directly [10] or by stabilizing ABP activity [11]. But again, possibly reduced serum testosterone concentrations cannot explain the different development of testicular and epididymal ABP, so much the more as ABP production by Sertoli cells is unlikely to be affected in streptozotocin-hyperglycaemic rats (Fig. $1 \mathrm{~L}$ ).

Therefore, a reduction of Sertoli cell ABP secretion or impaired $A B P$ transport from the testes to the epididymides seem to be more probable explanations for the results presented in this study. This assumption 
is supported by the observation that hypophysectomy, as well as administration of anti-LH serum, affects fluid secretion by the Sertoli cells and causes loss of ABP in the caput epididymidis in the long term [16]. A deficiency of LH might also be responsible for the impaired testicular ABP secretion in diabetes mellitus, although it cannot be excluded that testicular ABP secretion is affected via hormone-independent mechanisms.

In conclusion, it is suggested that streptozotocin-induced hyperglycaemia does not cause impaired ABP production by the Sertoli cells, but affects ABP secretion by, or ABP transport from, the testis, the result being a relative elevation of testicular and a relative diminution of epididymal ABP in diabetic animals.

Acknowledgement. Part of this study was supported financially by the Deutsche Forschungsgemeinschaft (SFB 113, C-3 and F-13).

\section{References}

1. Paz G, Homonnai ZT, Drasnin N, Sofer A, Kaplan R, Kraicer PF (1978) Fertility of the streptozotocin-diabetic male rat. Andrologia 10:127-136

2. Murray FT, Orth J, Gunsalus G, Weisz J, Li JB, Jefferson LS, Musto NA, Bardin CW (1981) The pituitary-testicular axis in the streptozotocin diabetic male rat: evidence for gonadotroph, Sertoli cell and Leydig cell dysfunction. Int $J$ Androl 4: 265-280

3. Pérez Díaz J, Benitez A, Fernández Galaz C (1982) Effect of streptozotocin diabetes on the pituitary-testicular axis in the rat. Horm Metab Res 14: 479-482

4. Kühn-Velten N, Waldenburger D, Staib W (1982) Evaluation of steroid biosynthetic lesions in isolated Leydig cells from the testes of streptozotocin-diabetic rats. Diabetologia 23: $529-533$

5. Oksanen A (1975) Testicular lesions of streptozotocin diabetic rats. Horm Res 6: 138-144

6. Rossi GL, Aeschlimann M (1982) Morphometric studies of pituitary glands and testes in rats with streptozotocin-induced diabetes. Andrologia 14: 532-542
7. Howland BE, Zebrowski EJ (1976) Some effects of experimentally-induced diabetes on pituitary-testicular relationships in rats. Horm Metab Res 8: 465-469

8. Sanborn BM, Elkington JSH, Chowdhury M, Tcholakian RK, Steinberger E (1975) Hormonal influences on the level of testicular androgen binding activity: effect of FSH following hypophysectomy. Endocrinology 96: 304-312

9. Hagenäs L, Ritzén EM, Plöen L, Hansson V, French FS, Nayfeh SN (1975) Sertoli cell origin of testicular androgen-binding protein ABp. Mol Cell Endocrinol 2: 339-350

10. Tindall DJ, Means AR (1976) Concerning the hormonal regulation of androgen binding protein in rat testis. Endocrinology 99: $809-818$

11. Tindall DJ, Mena CR, Means AR (1978) Hormonal regulation of androgen-binding protein in hypophysectomized rats. Endocrinology $103: 589-594$

12. Louis GB, Fritz IB (1979) Follicle-stimulating hormone and testosterone independently increase the production of androgenbinding protein by Sertoli cells in culture. Endocrinology 104: 454-461

13. Gunsalus GL, Larrea F, Musto NA, Becker RR, Mather JP, Bardin CW (1981) Androgen binding protein as a marker for Sertoli cell function. J Steroid Biochem 15:99-106

14. Ritzén EM, French FS, Weddington SC, Nayfeh SN (1974) Steroid binding in polyacrylamide gels: quantitation at steady state conditions. J Biol Chem 249: 6597-6604

15. Kirchhoff J, Soffie M, Rousseau GG (1979) Differences in the steroid-binding site specificities of rat prostate androgen receptor and epididymal androgen-binding protein $\mathrm{ABp}$. J Steroid Biochem 10: 487-497

16. Dym M, Madhwaraj HG (1977) Response of adult rat Sertoli cells and Leydig cells to depletion of luteinizing hormone and testosterone. Biol Reprod 17:676-696

Received: 17 June 1983

and in revised form: 6 February 1984

Dr. Nikolaus Kühn-Velten

Institut für Physiologische Chemie II

Universität Düsseldorf

Moorenstraße 5

D-4000 Düsseldorf

FRG 